\title{
New Perspective of Korean Social Cultural Diversity and Cultural Development: Protection and Inheritance of Folk Custom and Intangible Cultural Heritage
}

\author{
Xiaochuan $\mathrm{Ji}^{1,{ }^{*}}$, Xiaofei $\mathrm{Han}^{1}$ \\ ${ }^{1}$ Qingdao Vocational and Technical College of Hotel Management, Qingdao, Shandong, China \\ *Corresponding author
}

Keywords: Korea; cultural heritage; the Gangneung Danoje Festival; protection and inheritance.

\begin{abstract}
In recent years, the conflict between urban development and cultural protection has becomes more intense with the acceleration of urbanization progress of China. The protection of cultural heritage not only needs the perfection of relevant laws, but also requires the autonomous participation of the public. Public self-awareness is the basic premise of protecting tangible and intangible cultural heritage, while scholars are the intelligence security for the protection and inheritance of traditional culture. The actions and measures made by the Korea society in the aspects of cultural diversity and cultural development provide us with many beneficial references. Cultural heritage is the common wealth of all human being currently; every one, every country or the international society all has the responsibility and obligation to protect and inherit cultural heritage. This study explored and analyzed the cultural diversity and development of the Korea society in the perspectives of the protection and inheritance of folk custom and intangible cultural heritage.
\end{abstract}

\section{Introduction}

The urbanization of China has further developed since the reform and openness and the development of socialist marketing economy. The spiritual life of people changes to some extent with the constant improvement of material life; however, the cultural features of some cities gradually disappear [1]. Hence the protection of cultural heritage is a problematic issue existing in the current urban construction. The works made by Korea to protect and inherit its intangible cultural heritage are in the front end of the world. Korea is taking efforts to perfect relevant laws and regulations of cultural heritage protection and moreover, the care consciousness of the public on cultural heritage is constantly strengthened [2, 3].

In recent years, many scholars in China and abroad have made many relevant studies. For example, Deng X et al. [4] pointed out in 2014 that, human created wonderful intangible cultural heritage in the social development and historical progress and intangible cultural heritage as the fruit of creativity, imagination, intelligence and labor vividly displayed the diversity of human culture. In 2010, aiming at the features and problems of intangible cultural heritage protection practice, Leimgruber W. [5] discussed over intangible heritage protection theory such as traditional culture and folk inheritance in the aspects of the maintenance of cultural diversity and in situ conservation, the perfection of protection system and preserving means, the respect of community culture right and sustainable utilization. In 2012, Mclaughlin R. [6] proposed that the common heritage of human included cultural diversity which was one of the development motivations of human society. The works done to protect intangible cultural heritage can directly affect the protection of cultural diversity and the harmonious development of human society. Referring to a new perspective of the protection and inheritance of Korea social folk custom and intangible cultural heritage, this study investigated the cultural diversity and cultural development in China, aiming to help the protection and inheritance of Chinese cultural heritage. 


\section{Overview of intangible cultural heritage}

Intangible cultural heritage and anthropology both focus on culture and human. Intangible cultural heritage is the meaningful practice created by human in a long time of production and living. As it connects the inheritors with their surrounding world and their ancestors, such a meaningful form becomes a component of human culture. Korea is a country which carried out intangible cultural heritage protection works early. The protection intensity and development level of Korea intangible cultural heritage are both at the top around the world. Relevant data suggest that, totally 16 events are recognized as the world intangible cultural heritage currently. After half a century of efforts, Korea has gained great achievement in the protection of intangible cultural heritage. Many scholars consider Korea as an advanced country in intangible culture management [7-9]. We should realize the gap with Korea in the aspect of intangible cultural heritage protection rather than tangle at the affiliation of intangible cultural heritage with regard to Dragon Boat Festival. Besides, we should learn and refer to the experience and relevant mechanisms of Korea obtained after long-time practice in the aspect of intangible cultural heritage protection and development. The experience and mechanisms can provide beneficial enlightenment for the protection works of intangible cultural heritage in China and promote the protection and overall development level of Chinese intangible cultural heritage.

\section{The Gangneung Danoje Festival}

The origin of the Gangneung Danoje Festival. Like the Chinese Dragon Boat Festival, the Gangneung Danoje Festival in Korea is in the fifth day of the fifth lunar month as well. In literal meaning, Danoje means initial horse, i.e., the first horse day in May. Five is an odd number and the fifth day of the fifth lunar month has two odd numbers. Similar to Chinese culture, Korea culture also pays much attention to the encounter of odd days; therefore, Korea people set the fifth day of the fifth lunar month as a great festival day [10-13]. However, no definite literal data can testify the specific generation time of the festival. What we know is that, the Gangneung Danoje Festival has existed since Xinluo age. On that day, both the royal household and plain citizen enjoy the day in a happy atmosphere.

Celebration ceremony of Korean Gangneung Danoje Festival. Though Korean Gangneung Danoje Festival is similar to Chinese Dragon Boat Festival and the festival is of certain possibility being transmitted from China at the earliest, Korean Gangneung Danoje Festival is considered as the festival of Gangneung people actually if we analyze in the aspect of celebration ceremony. Gangneung people regard the mythological figures who they believe in as the sacrificing objects; moreover, the etiquette of the sacrifice has distinct local features of Gangneung; scenery and entertainment in the festival, especially, can reflect the cultural deposits of Gangneung people which have been inherited for generations [14-16].

The role of government in the protection of intangible cultural heritage. Government in every country and nation manages folk customs in different forms. Such a kind of management which integrates with government right has stronger influence; however, the management effect can be effective or negatively effective because the influence of right can be positive or negative [17-19]. In practice, the system security for the protection and inheritance of traditional culture actually refers to the effective management of government. We can find out successful examples in the measures and actions of Korean government, for example, the survival of Gangneung pungmul. That folk custom is in a close connection with the farming consciousness of the Korean nation, i.e., farmer is the foundation of the country. Pungmul is quite popular among the public no matter in sacrificial rites or yearly local customs in one year. But due to various reasons, pungmul has got into trouble for many times. The government adopts some effective measures for positive interference, for example, positive organization of national folk custom art competition, the support for the establishment of Gangneung pungmul protection society, etc. These measures can promote the effective inheritance and innovation of folk custom phenomenon and lay a good basis. Those practices also testify that, the measures have achieved excellent effect. 


\section{Worries brought by the commercialization of Korean folk custom performance}

The protection of cultural heritage in Korean society is more than the discussion on the protection of cultural heritage, but also includes relevant analysis of business development and travel. Korean capital began to focus on the research and development in the expanded intangible cultural heritage activities with the expansion of non-intangible cultural heritage activities [20-24]. Businessmen are taking efforts to develop Korean cultural heritage and intangible cultural heritage into products for commercial trade. Moreover, the commercialization phenomenon has emerged in Korean intangible cultural heritage in early stage. However, the phenomenon that petty dealers peddle products by yelling has not been seen so far. The commercialization of Korean intangible cultural heritage puzzles people [25-27]. We all know that, once intangible cultural heritage is commercialized, the scale and modeling development of intangible cultural heritage will happen, which can lead to the loss of the original cultural connotation of Korean traditional culture.

To inhibit the alienation of intangible cultural heritage during commercial development and ensure the original ecological transmission of intangible cultural heritage, Korea released Cultural Property Protection Laws (revised in 2004) in January 1962 to speculate the pyramidal system for the live treasure of human. The system mainly includes three aspects of content.

The first content is to name the inheritors in the name of the country. In Korea, national-level intangible cultural heritage inheritors usually are endowed with the title of "the holder of important cultural property" or "national treasure" . The inheritors are outstanding national representatives of cultural heritage inheritors who master traditional cultural skills and folk cultural skills or traditional manufacture and processing techniques. So far, only 213 inheritors have gained those titles. Inheritors who gain such titles will be greatly respected by the public and therefore have high social status.

The second content is the special financial support of the government to the inheritors. The Korean government establishes special subsidy for the holders of important cultural property. The subsidy will be given to inheritors titled by the government as the financial security for maintaining normal life and inheriting culture. Korea government establishes two kinds of special subsidy, i.e., cultural inheritance subsidy and living subsidy. The cultural inheritance subsidy is given to the titled inheritors as the expenditure for public performance and exhibition or as the funds for research and skill or artistic skill development according to the actual demand of cultural inheritance. Each titled inheritor will be given one million Korean won per month as the financial security for daily life as well as relevant medical security.

The third content is the relevant responsibilities and obligations of the holder of important cultural property. Under the respect of the society and the support of national special financial fund, the holder of important cultural property should perform the following responsibilities and obligations: more than two times of domestic public performance tasks every year and skill or artistic skill teaching for staffs in the latter two layers of the pyramid; staffs in the latter two layers of pyramid should research and study traditional skills or artistic skills positively under the leading of holders [28, 29] and they should be able to succeed when holders cannot undertake obligations any more or pass away.

\section{The enlightenment of Korean intangible cultural heritage protection to China}

Not only Korea pays much attention to intangible cultural heritage, but also China begins to protect intangible cultural heritage in different forms. Intangible culture is both a culture and an important resource for developing economy. In competition theory of economics, maintaining product differentiation is considered as the key for keeping the share and competition of a product in market. The difference of cultural product first depends on the peculiarity of value and expression method. The difference between the special national culture of China and other cultures in the world will be the advantage depended by the economic development of China. We have not realized the loss of our culture and the opportunity to further develops our culture which is caused by the backward awareness in the aspect of protecting intangible cultural heritage and capital investment. 
Implementing commercial development and cultivating better value of intangible cultural heritage is an inevitable road to protect and renew intangible cultural heritage of China.

\section{Conclusion}

The study, interpretation, transfer and expression of intangible cultural heritage should be an important aspect in the construction of discourse system of China. Currently, it is especially important to interpret our intangible cultural heritage in a higher theoretical perspective and thoroughly understand the subtle relationship between the essence of intangible cultural heritage and us. Moreover, we need to pay attention to transfer and express the understanding and study of intangible cultural heritage in proper ways. We should transfer our intangible cultural heritage with the long history and intelligence of Chinese nation to different people and groups in different ways, approaches and platforms.

\section{References}

[1] Xia Y, Zhao W. The promotion of cultural development by landscape lighting: A study about the integration between native culture and landscape lighting in Tianjin. // International Conference on Electrical and Control Engineering. IEEE, 2011:3722-3725.

[2] Mortaki S. The contribution of vocational education and training in the preservation and diffusion of cultural heritage in Greece: the case of the specialty "Guardian of Museums and Archaeological Sites". International Journal of Humanities \& Social Science, 2012, 58(6):51-58.

[3] Jeroscenkova L, Kruzmetra M, Rivza B. International vision of the significance and availability of cultural heritage. // "economic Science for Rural Development". International Scientific Conference, Jelgava, Latvia, 24-25 April, 2014:7157-66.

[4] Deng X, Shen C. Applied-Digitization Technology and Animation Abstract in the Protection and Inheritance of Intangible Cultural Heritage. Applied Mechanics \& Materials, 2014, 556-562:6506-6510.

[5] Leimgruber W. Switzerland and the UNESCO Convention on Intangible Cultural Heritage. Journal of Folklore Research: An International Journal of Folklore \& Ethnomusicology, 2010, 47(1-2):161-196.

[6] Mclaughlin R. Making it personal: digital printing allows marketers to individualize each mailing.(includes related article on available digital printing software and hardware). Glasnik Etnografskog Instituta Sanu, 2012, 60(LX):9-23.

[7] Li H M, Shan J. Construction of Geographical Indications Protective Pattern on Intangible Cultural Heritages. Advanced Materials Research, 2011, 347-353:409-412.

[8] Huang X J, Zhou Q. To Construct a Management System for Tourism Resources of Intangible Cultural Heritage. Journal of the Royal Anthropological Institute, 2011, 403-408(3):377-382.

[9] Yupsanis A. Cultural Property Aspects in International Law: The Case of the (Still) Inadequate Safeguarding of Indigenous Peoples' (Tangible) Cultural Heritage. Netherlands International Law Review, 2011, 58(3):335-361.

[10] Ferroli P, Acerbi F, Tringali G, et al. Venous sacrifice in neurosurgery: new insights from venous indocyanine green videoangiography. Journal of Neurosurgery, 2011, 115(1):18-23.

[11] Coiro J. Predicting Reading Comprehension on the Internet: Contributions of Offline Reading Skills, Online Reading Skills, and Prior Knowledge. Journal of Literacy Research, 2011, 43(43):352-392.

[12] Drost B, Ulrich M, Navab N, et al. Model globally, match locally: Efficient and robust 3D object recognition. // IEEE Conference on Computer Vision \& Pattern Recognition. 2010:998-1005.

[13] Ryan G. Men Who Defaulted in the Greatest Game of All: Sport, Conscientious Objectors and Military Defaulters in New Zealand 1916 - 1923. International Journal of the History of Sport, 2014, 31(31):2375-2387. 
[14] Mark Bhatti, Andrew Church, Amanda Claremont, et al. 'I love being in the garden' : enchanting encounters in everyday life. Social \& Cultural Geography, 2008, volume 10(1):61-76.

[15] Berger R, Tiry M. The enchanting forest and the healing sand - Nature therapy with people coping with psychiatric difficulties. Arts in Psychotherapy, 2012, 39(5):412-416.

[16] Gentes A, Jutant C, Guyot A, et al. Designing Mobility: Pervasiveness as the Enchanting Tool of Mobility. // Mobile Computing, Applications, and Services. Springer Berlin Heidelberg, 2010:374-382.

[17] Chu P, Chang C, Chen C, et al. Countering negative country-of-origin effects: The role of evaluation mode. European Journal of Marketing, 2010, volume 44(44):1055-1076.

[18] Lu W, Ding W, Zhang J, et al. Biochar suppressed the decomposition of organic carbon in a cultivated sandy loam soil: A negative priming effect. Soil Biology \& Biochemistry, 2014, 76(1):12-21.

[19] Tan K T, Huang H H, Sun C T. Blast-wave impact mitigation using negative effective mass density concept of elastic metamaterials. International Journal of Impact Engineering, 2014, 64(2):20-29.

[20] Elvan Yalçı nkaya. Creative Drama Study about Intangible, Cultural Heritage: Turkish Wedding, Traditions. Creative Education, 2015, 06(1):22-31.

[21] Ohinata F. Unesco's activities for the safeguarding of the intangible cultural heritage in the horn of Africa. African Study Monographs Supplementary Issue, 2010, 41:35-49.

[22] Silva P. Pride or shame? The "Mané do Rosário": expression of intangible cultural heritage of Poxim, Coruripe-AL, Brazil. Pasos Revista De Turismo Y Patrimonio Cultural, 2013:343-350.

[23] Kolar E B, Galzina V, Matanović D. Towards a safeguarding concept of the intangible cultural heritage in Slavonia, Baranya and Syrmia - Aspects of digitization, processing, conservation and dissemination of sound, image and shape. Medijska Istra ivanja, 2014, 20(2):213-231.

[24] Wang K A, Liao Y C, Chu W W, et al. Digitization and Value-Add Application of Bamboo Weaving Artifacts. // Digital Libraries: For Cultural Heritage, Knowledge Dissemination, and Future Creation. Springer Berlin Heidelberg, 2011:16-25.

[25] Vanhoutte B, Ceusters J, Proft M P D. The 'tubing' phenomenon in commercial cultivation of Guzmania: morphology, physiology and anatomy. Scientia Horticulturae, 2016, 205:112-118.

[26] Duan X, Zhu M Q. Community exterior space and community commercial interactive fusion phenomenon analysis. // Environmental Science and Information Application Technology (ESIAT), 2010 International Conference on. IEEE, 2010:462-465.

[27] Fujimoto T, Shiozawa Y. Inter and Intra Company Competition in the Age of Global Competition: A Micro and Macro Interpretation of Ricardian Trade Theory. Evolutionary \& Institutional Economics Review, 2012, 8(2):193-231.

[28] Jenison E L, Gil K M, Lendvay T S, et al. Robotic surgical skills: acquisition, maintenance, and degradation . Journal of the Society of Laparoendoscopic Surgeons, 2012, 16(2):218-28.

[29] González-Fernández-Villavicencio N, Domínguez-Aroca M I, Calderón-Rehecho A. State of the Art of Information Literacy in Spanish University Libraries and a Proposal for the Future. // Worldwide Commonalities and Challenges in Information Literacy Research and Practice. Springer International Publishing, 2013:288-294. 